\title{
Development of Bioadhesive Buccal Tablets of Nicorandil Using a Factorial Approach
}

\section{Faktöriyel Yaklaşım ile Nikorandil İçeren Biyoadezif Bukkal Tabletlerin Geliştirilmesi}

\author{
(D) Rajendra KOTADIYA ${ }^{1 *}$, (D) Karan SHAH² \\ ${ }^{1}$ Charotar University of Science and Technology, Ramanbhai Patel College of Pharmacy, Changa, India \\ 2Sigma Institute of Pharmacy, Vadodara, India
}

\begin{abstract}
Objectives: In the present investigation, bioadhesive buccal tablets were prepared using the sustained-release polymer hydroxypropyl methylcellulose (HPMC) K100M, bioadhesive polymer neem gum, and an impervious backing layer of ethyl cellulose. Nicorandil is sensitive to the first-pass effect; therefore, a buccal-adhesive dosage form can avoid this effect.

Materials and Methods: We used the direct compression technique to prepare the tablet formulation. A $3^{2}$ full factorial design was composed in which the amounts of HPMC K100M (X1) and neem gum (X2) were chosen as the independent variables and the dependent variables were the percentage drug release at $6 \mathrm{~h}(\mathrm{Y} 1)$ and mucoadhesive strength in grams (Y2). Various in vitro parameters, i.e. thickness, friability, hardness, weight variation, surface $\mathrm{pH}$, moisture absorption ratio, dissolution studies, and drug release kinetics, and ex vivo parameters like mucoadhesive strength and mucoadhesion time were determined for the prepared tablets. We subjected the optimized batch to a comparison with the marketed formulation and stability studies were performed.

Results: The formulation containing a 50:50 ratio of neem gum and HPMC K100M (F5) was considered optimum. The zero-order release kinetics model best fitted the optimized batch release profile, suggesting the system would release the drug at a constant rate.

Conclusion: The release by the optimized formulation of the drug at a sustained rate along with its bioadhesive nature showed that the buccal route can be an option for the administration of nicorandil.
\end{abstract}

Key words: Nicorandil, neem gum, buccal tablets, factorial design

öz

Amaç: Bu araştırmada, biyoadesif bukkal tabletler sürekli salımlı polimer hidroksipropil metilselüloz (HPMC) K100M, biyoadesif polimer neem sakızı ve geçirimsiz etil selüloz arka tabaka kullanılarak hazırlanmıștır. Nikorandil ilk geçiş etkisine karşı duyarlıdır. Bu nedenle, bukal adesif dozaj formu bu etkiyi önleyebilir.

Gereç ve Yöntemler: Tablet formülasyonu hazırlamak için doğrudan sıkıştırma tekniği kullanılmıştır. HPMCK 100M (X1) ve neem sakızı (X2) miktarları bağımsız değişken olarak ve 6. saat (Y1) ilaç salımı yüzdesi ve gram biriminde mukoadhersif güç yüzde bağımlı değişkenler olarak seçilerek $3^{2}$ tam faktöriyel tasarımı oluşturulmuştur. Hazırlanan tabletler için farklı in vitro parametreler (kalınlık, ufalanma, sertlik, ağıllık sapması, yüzeysel pH'sı, nem absorpsiyon oranı, çözünme çalışmaları ve ilaç salım kinetikleri) ve ex vivo parametreler (mukoadesif güç ve mukoadesif zaman) belirlenmiştir. Optimize etilen seri piyasadaki formülasyon ile karşılaştırılmış ve stabilite çalışmaları yapılmıştır.

Bulgular: 50:50 oranında neem zamkı ve HPMC K100M içeren formülasyon (F5)'in en uygun olduğu kabul edilmiştir. Sıfır derece salım kinetiği modeli optimize seri salım profiline en iyi düzeyde uymuştur ve bu sistemin ilacı sabit bir hızda salım sağlayacağını belirtmektedir.

Sonuç: İlacın optimize edilmiş formülasyonunun biyoadesif özelliğinin yanında sürdürülebilir hızla salımı nikorandilin bukkal yol ile uygulanmasının bir seçenek olacağını göstermiştir.

Anahtar kelimeler: Nikorandil, neem sakızı, bukkal tabletler, faktöriyel tasarım

*Correspondence: E-mail: rajendrakotadiya.ph@charusat.ac.in, Phone: +912697265146 ORCID-ID: orcid.org/0000-0002-5484-874X

Received: 30.04.2019, Accepted: 18.07.2019

๑Turk J Pharm Sci, Published by Galenos Publishing House. 


\section{INTRODUCTION}

Hypertension and angina pectoris are cardiovascular diseases for which constant monitoring is crucial. Angina pectoris is a medical condition that causes chest pain by reduced blood flow to the heart. Potassium channel openers are currently regarded as an important drug class for the treatment of such conditions. A primary medicinal agent that possesses an ability to tackle such a situation is nicorandil, a vasodilatory drug. ${ }^{1-3}$ It appears to be active in all types of angina pectoris and has the twin properties of nitrate and $\mathrm{K}^{+}$adenosine triphosphate channel agonist. The major problem with orally administered nicorandil is its first-pass metabolism, which gives about $75 \%$ systemic bioavailability. Moreover, it has a short elimination half-life $(1 \mathrm{~h})$, which necessitates frequent administration of the drug (10 to $20 \mathrm{mg}$ twice daily).4-6 Thus, higher fluctuation of drug concentration may give rise to undesirable side effects. In summary, there is a strong requirement for a patient-friendly sustained-release formulation of nicorandil to reduce the frequency of administration.

Such a requirement for an oral dosage form can be fulfilled by employing a buccal bioadhesive drug delivery system. It is a captivating substitute to the oral route of drug administration that overcomes the deficiencies associated with the latter mode of administration. Precisely it prevents any chance of reductant hepatic metabolism, avoiding unneeded drug degradation in the upper GIT, and also it increases the contact between drug and absorbing surface..$^{7-11}$ Moreover, such type of delivery is considered safer since drug absorption can be concluded any time if toxicity occurs due to it by removal of the formulation from the site of application. ${ }^{12-14}$

Thus, in the present research, buccal bioadhesive tablets of nicorandil were prepared using the sustained-release polymer hydroxypropyl methylcellulose (HPMC) K100M, ${ }^{10,15}$ bioadhesive polymer neem gum, ${ }^{16}$ and an impermeable backing layer of ethyl cellulose. Buccal bioadhesive tablets were prepared by direct compression method employing a $3^{2}$ factorial design in which the amounts of HPMC K100M $\left(X_{1}\right)$ and neem gum $\left(X_{2}\right)$ were selected as independent variables and their effects on dependent variables, i.e. percentage drug release at $6 \mathrm{~h}\left(\mathrm{Y}_{1}\right)$ and mucoadhesive strength in grams $\left(\mathrm{Y}_{2}\right)$, were studied.

\section{MATERIALS AND METHODS}

\section{Materials}

Nicorandil was a gratis sample from Sun Pharma Laboratories Ltd. (East Sikkim). Neem gum was purchased from the local market and the remaining materials were purchased from Chem Dyes Corporation (Vadodara, Gujarat, India).

\section{Methods}

\section{Drug-excipients compatibility study}

Accurately weighed (3 mg) nicorandil was taken and mixed thoroughly with $100 \mathrm{mg}$ of potassium bromide (dried at 40$50^{\circ} \mathrm{C}$ ). The mixture was compressed into pellets (under $10-\mathrm{t}$ pressure) using a hydraulic press followed by scanning between 4000 and $400 \mathrm{~cm}^{-1}$ using an fourier transform-infrared (FT-IR)
410 PC spectrophotometer. The obtained IR spectra of pure drug (Figure 1a) were compared with those of the reference standard (Figure 1b) taken from Indian Pharmacopoeia as well as with the IR spectra (Figure 1c) of the prepared nicorandil tablet formulation to check the drug excipient compatibility.

\section{Preparation of buccal tablets}

Initially, the drug was accurately measured and mixed thoroughly with mannitol on butter paper using a stainless-steel spatula. Except the lubricant, all the additives were blended for $10 \mathrm{~min}$ by geometric dilution. After uniform blending of the additives, lubricant was added followed by mixing for $2 \mathrm{~min}$. Next, $100 \mathrm{mg}$ of such blends of each formulation was pre-compressed on a 10-station rotary tablet punching machine at a low compression force, resulting in single-layered core tablets $8 \mathrm{~mm}$ in diameter. The prepared core tablet was placed in the center of the $12-\mathrm{mm}$ lower punch and the backing layer of $100 \mathrm{mg}$ of ethyl cellulose was added around and over the core tablet; the two layers were then compressed into a mucoadhesive bilayer tablet. A tablet $(200 \mathrm{mg}$ ) was formed whose thickness was 1.6 to 1.8

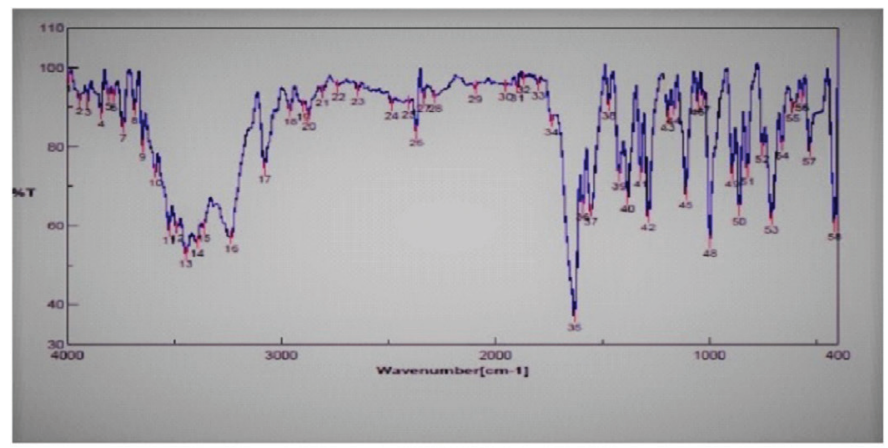

1(a)

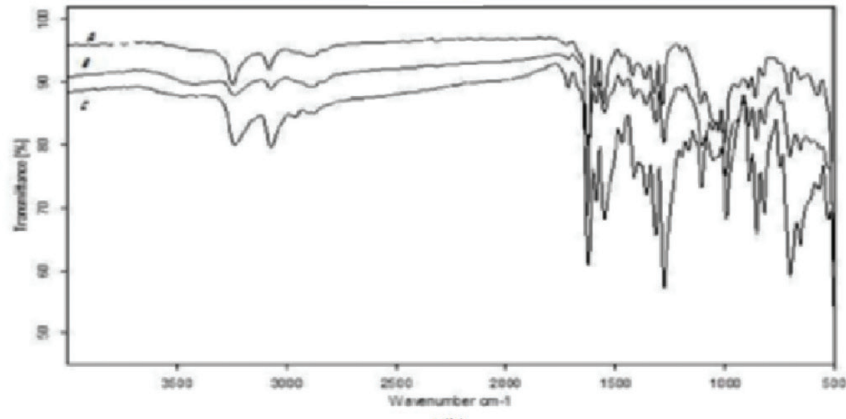

1(b)

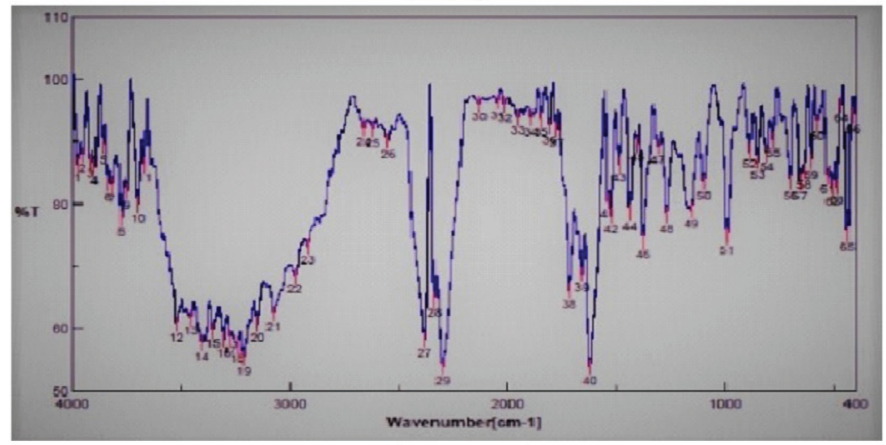

$1(\mathrm{c})$

Figure 1 a, b, c. FT-IR spectra FT-IR: Fourier transform-infrared 
$\mathrm{mm}$. Table 1 shows the results of preliminary trials to evaluate the bioadhesive polymers and Table 2 depicts formulations to evaluate the sustained-release characteristics of various compositions.

\section{Factorial batches}

Based on the preliminary studies, a $3^{2}$ full factorial design was constructed in which the amounts of HPMC K100M $\left(X_{1}\right)$ and

\section{Table 1. Preliminary trial for selection of bioadhesive polymer} (B1-B5)

\begin{tabular}{llllll} 
Ingredients & B1 & B2 & B3 & B4 & B5 \\
\hline Core tablet & & & & & \\
\hline Nicorandil & 10 & 10 & 10 & 10 & 10 \\
\hline Neem gum & 30 & - & - & - & - \\
\hline Guar gum & - & 30 & - & - & - \\
\hline Na alginate & - & - & 30 & - & - \\
\hline Carbopol 934 & - & - & - & 30 & - \\
\hline Xanthan gum & - & - & - & - & 30 \\
\hline PVP K30 & 10 & 10 & 10 & 10 & 10 \\
\hline Mannitol & 68 & 68 & 68 & 68 & 68 \\
\hline Magnesium stearate & 1 & 1 & 1 & 1 & 1 \\
\hline Aspartame & 1 & 1 & 1 & 1 & 1 \\
\hline Backing layer & & & & & \\
\hline Ethyl cellulose & 80 & 80 & 80 & 80 & 80 \\
\hline Total (mg) & 200 & 200 & 200 & 200 & 200 \\
\hline PP Ponvilyrolid & & & & &
\end{tabular}

PVP: Polyvinylpyrrolidone

Table 2. Compositions of formulation for optimization of sustained release polymer (S1-S3)

\begin{tabular}{llllll} 
Ingredients & S1 & S2 & S3 & & \\
\hline Core tablet & & & & & \\
\hline Nicorandil & & 10 & & 10 & 10 \\
\hline Neem gum & 30 & - & - & & 30 \\
\hline HPMC K4 100M & - & 30 & - & & \\
\hline HPMC K4 M & - & - & 30 & & \\
\hline HPMC K15 LV & 10 & 10 & 10 & & \\
\hline PVP K30 & 38 & 38 & 38 & & \\
\hline Mannitol & 1 & 1 & 1 & & \\
\hline Magnesium stearate & 1 & 1 & 1 & & \\
\hline Aspartame & & & & & \\
\hline Backing layer & 80 & 80 & 80 & \\
\hline Ethyl cellulose & 200 & 200 & 200 & \\
\hline Total (mg) & & & &
\end{tabular}

HPMC: Hydroxypropyl methylcellulose, PVP: Polyvinylpyrrolidone neem gum $\left(X_{2}\right)$ were selected as independent variables and their levels were defined. The dependent variables were $\%$ drug release at $6 \mathrm{~h}\left(\mathrm{Y}_{1}\right)$ and mucoadhesive strength in grams $\left(Y_{2}\right)$. Table 3 gives details regarding the employed factorial design. ANOVA was performed using the software Design Expert 11.0 demo version (State-ease) and the responses were studied.

\section{Evaluation of buccal tablets}

\section{Thickness}

A vernier caliper was used to calculate the thickness of tablets $(n=10)$ and the mean tablet thickness was calculated.

\section{Friability and hardness}

Friability ( $n=20)$ and hardness $(n=3)$ were measured by a Roche friabilator and a Monsanto type hardness tester, respectively. ${ }^{17}$

\section{Weight variation}

Tablets $(n=20)$ were weighed individually and their weight variation was found by comparing these weights to the label claim. ${ }^{17}$

\section{Drug contents}

The prepared tablets $(n=10)$ were powdered and an amount corresponding to $10 \mathrm{mg}$ of nicorandil was accurately weighed. The powder was extracted with a volume of buffer solution (phosphate buffer saline, $\mathrm{pH}$ 6.8) and analyzed using a spectrophotometer at $262 \mathrm{~nm}$ after appropriate dilution.

\section{Surface $p H$}

To evaluate the possibility of the prepared tablets causing irritation to the oral mucosa, surface $\mathrm{pH}$ studies were performed. Tablets were soaked in $12 \mathrm{~mL}$ of buffer solution (phosphate buffer saline, $\mathrm{pH}$ 6.8) and allowed to swell for $2 \mathrm{~h}$ at room temperature. $\mathrm{A} \mathrm{pH}$ meter containing a glass electrode was utilized to find out the $\mathrm{pH}$ of the resultant swelled tablets

Table 3. $3^{2}$ Experimental design for buccal tablet formulation

\begin{tabular}{lccccccccc} 
Ingredients & F1 & F2 & F3 & F4 & F5 & F6 & F7 & F8 & F9 \\
\hline Core tablet & & & & & & & & & \\
\hline Nicorandil & 10 & 10 & 10 & 10 & 10 & 10 & 10 & 10 & 10 \\
\hline Neem gum & 20 & 20 & 20 & 30 & 30 & 30 & 40 & 40 & 40 \\
\hline HPMC K4100M & 20 & 30 & 40 & 20 & 30 & 40 & 20 & 30 & 40 \\
\hline Mannitol & 58 & 48 & 38 & 48 & 38 & 28 & 38 & 28 & 18 \\
\hline PVP K30 & 10 & 10 & 10 & 10 & 10 & 10 & 10 & 10 & 10 \\
\hline $\begin{array}{l}\text { Magnesium } \\
\text { stearate }\end{array}$ & 1 & 1 & 1 & 1 & 1 & 1 & 1 & 1 & 1 \\
\hline Aspartame & 1 & 1 & 1 & 1 & 1 & 1 & 1 & 1 & 1 \\
\hline Barly
\end{tabular}

Backing layer

Ethyl cellulose $\begin{array}{lllllllll}80 & 80 & 80 & 80 & 80 & 80 & 80 & 80 & 80\end{array}$

Total weight in mg 200200200200200200200200200

HPMC: Hydroxypropyl methylcellulose, PVP: Polyvinylpyrrolidone 
by bringing the glass electrode into contact with the surface of the tablet and allowing it to equilibrate for $1 \mathrm{~min}^{18}$

\section{Moisture absorption ratio}

Hot water was taken and the required quantity of agar ( $5 \% \mathrm{w} / \mathrm{v}$ ) was added to it. The resultant solution was added to petri plates and inducted to solidify. Previously, vacuum dried nicorandil buccal tablets $(n=6)$ were taken, weighed individually, and one was laminated with cellophane tape (impermeable backing membrane). The tablets were then placed individually in petri plates so that their other side was in contact with the agar medium, followed by incubation at $37^{\circ} \mathrm{C}$ for $1 \mathrm{~h}$. After incubation, the buccal tablets were reweighed, and the percentage of moisture absorption was calculated using the following formula:

\% Moisture absorption=[(Final weight - Initial weight $) /$ Initial weight] $\times 100$

\section{Ex vivo mucoadhesive strength}

Ex vivo mucoadhesive strength was determined using a modified balance method. On the day of the experiment, the authors visited a nearby slaughterhouse and collected surgically cut out goat buccal mucosa, which can be used within 2 h of slaughter, a model substrate used for the present study. To prevent it going rotten, a piece of buccal mucosa was kept in Krebs buffer and stored at $4^{\circ} \mathrm{C}$ for $2 \mathrm{~h}$. The goat mucosa reached room temperature before further use. This model substrate was then tied to a glass slide to provide it with mechanical strength. On that membrane a tablet was gently put with manual pressure for 5 min after moistening with fluid, which led to bioadhesion. To that biologically attached tablet water was added to detach it from the model substrate, and the amount of water (in grams) needed to detach the tablet from the surface was determined as mucoadhesive strength. Such a procedure was repeated three times and the average mucoadhesive strengths were reported. ${ }^{19,20}$

\section{Ex vivo mucoadhesion time}

Freshly cut goat buccal mucosa was used for the measurement of ex vivo mucoadhesion time $(n=3)$ according to the reported method. Fresh goat buccal mucosa was collected and maintained as described above. A glass slide was taken and excised goat buccal mucosa was tied onto it. Upon this goat buccal membrane a bioadhesive side of the tablet, previously wetted with fluid, was pasted and light force was applied with a fingertip for $30 \mathrm{~s}$. The glass slide along with the pasted tablet was placed in a beaker containing $200 \mathrm{~mL}$ of phosphate buffer ( $\mathrm{pH}$ 6.8) and it was kept at $37 \pm 1^{\circ} \mathrm{C}$. The beaker containing the entire assembly was slowly stirred similar to the buccal cavity and the entire assembly was monitored for $12 \mathrm{~h}$. The ex vivo mucoadhesion time was calculated as the time required to detach the tablet from the goat membrane that was tied to a glass slide..$^{19,20}$

\section{Drug release studies}

A method previously reported by Daravath et al. ${ }^{21}$ for furosemide sustained release bilayered buccal tablets was simply followed in the present drug release studies using the
US Pharmacopeia XXIII rotating paddle apparatus. An instant adhesive (cyanoacrylate adhesive) was used for pasting the backing layer of the buccal tablet on a glass slide. The slide was then placed at the bottom of the dissolution vessel containing $250 \mathrm{~mL}$ of phosphate buffer saline $(\mathrm{pH}$ 6.8), which was maintained at $37 \pm 0.5^{\circ} \mathrm{C}$ and rotated at $50 \mathrm{rpm}$ throughout the experiment. Samples $(10 \mathrm{~mL})$ were withdrawn at predetermined time intervals in sink condition, followed by filtering through Whatman filter $(0.45 \mu \mathrm{m})$ paper and analysis by ultraviolet (UV) spectrophotometer at $262 \mathrm{~nm}$.

\section{Ex vivo permeation of drug from buccal tablets}

Ex vivo permeation of drug from buccal tablets was performed using a Franz diffusion cell through porcine buccal mucosa at $37 \pm 0.5^{\circ} \mathrm{C}$ and at $50 \mathrm{rpm}$. Fresh porcine buccal mucosa was obtained from a local slaughterhouse and used within $2 \mathrm{~h}$ of slaughter. The mucosal membrane was separated by removing the underlying fat and loose tissues, and washed with distilled water and then with phosphate buffer $\left(\mathrm{pH} \mathrm{6.8)}\right.$ at $37^{\circ} \mathrm{C}$. The fresh porcine buccal mucosa was cut into pieces and washed with phosphate buffer ( $\mathrm{pH}$ 6.8). The membrane was collected and was stored at $4^{\circ} \mathrm{C}$ in Krebs buffer. This membrane was arranged between the two chambers and phosphate buffer saline ( $\mathrm{pH}$ 6.8) was used to fill the receiver chamber. To the donor chamber was added $1 \mathrm{~mL}$ of phosphate buffer saline and a buccal tablet was suspended there. Aliquots of $5 \mathrm{~mL}$ samples were collected at predefined times. The collected samples were filtered, suitably diluted, and the amount of drug permeated was determined using a double beam UV spectrophotometer at $\lambda_{\text {max }}=262 \mathrm{~nm}$. The flux $(J)$ and permeability coefficient $(P)$ were calculated using the following formulae:

$J=[d Q / d t] \div \triangle C A$

$P=[d Q / d t] \div A$

Here $\mathrm{J}$ is flux $\left(\mathrm{mg} / \mathrm{h} \mathrm{cm}^{2}\right), P$ is a permeability coefficient $(\mathrm{cm} / \mathrm{h})$, $\mathrm{dQ} / \mathrm{dt}$ is the slope of the steady-state portion of the curve, $\Delta \mathrm{C}$ is the difference in concentration across the membrane, and $A$ is the area of diffusion $\left(\mathrm{cm}^{2}\right) .^{22}$

\section{ANOVA studies}

To evaluate the effect of independent variables on the responses, ANOVA was applied to the nine formulations prepared using Design Expert software. The $p$ values for the respective responses were also calculated to check whether the effect was statistically significant or not.

\section{Drug release kinetics}

To define the kinetics of drug release, the dissolution profile of the optimized batch (F5) was fitted to various models such as zero order, first order, Higuchi, Hixon Crowell, Korsmeyer, and Peppas. ${ }^{23}$

\section{Stability studies}

To determine the change in bioadhesive strength and in vitro release profile during storage, a 3-month short-term stability study for the optimized batch was performed at $40 \pm 2^{\circ} \mathrm{C}$ in a stability chamber with $75 \pm 5 \%$ relative humidity $(\mathrm{RH})$. Tablets 
were taken out at 1-month intervals and evaluated for any change in bioadhesive strength and in vitro drug release pattern. The difference factor $\left(f_{1}\right)$ and similarity index $\left(f_{2}\right)$ were calculated to find out the similarity between the dissolution profile of batch F5 before and after storage at the level of significant $(p<0.05)$ by using the paired $t$-test.

The formulae to calculate difference factor $\left(f_{1}\right)$ and similarity index $\left(f_{2}\right)$ are as follows:

$\mathrm{f}_{1}=\left\{\sum|\mathrm{Rt}-\mathrm{Tt}| \div \sum \mathrm{Rt}\right\} \times 100$

$\mathrm{f}_{2}=50 \log \left\{\left[1+\sum_{n=1}^{\mathrm{n}}(\mathrm{Rt}-\mathrm{Tt})^{2}\right]^{0.5} \times 100\right\}$

Here $t$ is 1 to $n, n$ is the dissolution time, and $R_{t}$ and $T_{t}$ are the reference and test dissolution value at time $t .{ }^{24,25}$

\section{RESULTS AND DISCUSSION}

\section{Drug excipient compatibility study}

FT-IR spectroscopy was employed to study any kind of interaction between the drug and additives used in the formulation. As per the FT-IR graph, no significant shift in the positions of the wave numbers was found for the formulation (F5) when compared to that of the pure drug values, which inferred no interaction between the drug and the employed additives in the formulation (Figure 1).

\section{Preliminary study}

Initially, the study was started with the preparation of preliminary tablets using various natural polymers to check their bioadhesive properties along with tableting properties and the same were compared with synthetic polymer (Carbopol 934). Table 4 shows the evaluation results for these formulations, which indicated that batch B1, which contained neem gum, has better bioadhesive strength as well as hardness. Hence, neem gum was chosen as a bioadhesive polymer for further study. To assess the synergistic sustained-release characteristics of neem gum along with different grades of HPMC, tablet formulations (S1, S2, and S3) were prepared and checked with respect to drug release for $12 \mathrm{~h}$. It was found that formulations S2 and S3 (containing HPMC K4M and HPMC K15 LV) were not able to sustain drug release for $12 \mathrm{~h}$, whereas S1 (containing neem gum and HPMC K4 100M) showed sustained drug release for $12 \mathrm{~h}$ as depicted in Table 5. Such sustained effect would be needed for our study and hence was selected for further study.

Table 4. Evaluation of preliminary batches for selection of bioadhesive polymer

\begin{tabular}{lll} 
Batches & $\begin{array}{l}\text { Hardness } \\
\left(\mathrm{kg} / \mathrm{cm}^{2}\right)(\mathrm{n}=3)\end{array}$ & $\begin{array}{l}\text { Mucoadhesive strength } \\
\text { (gram force })(\mathrm{n}=3)\end{array}$ \\
\hline B1 & $5.74 \pm 0.75$ & $19.07 \pm 1.12$ \\
\hline B2 & $5.86 \pm 0.67$ & $17.45 \pm 1.14$ \\
\hline B3 & $5.34 \pm 0.47$ & $17.01 \pm 1.11$ \\
\hline B4 & $6.47 \pm 0.42$ & $21.24 \pm 0.99$ \\
\hline B5 & $5.14 \pm 0.33$ & $16.67 \pm 1.10$ \\
\hline
\end{tabular}

\section{Full factorial design}

\section{Physico-chemical parameters}

The prepared factorial formulations were evaluated for various physicochemical parameters. From the results, it was found that the weight variation within 7.5\% deviation, hardness (4.33$5.71 \mathrm{~kg} / \mathrm{cm}^{2}$ ), thickness (1.69-1.86 mm), friability LT 1\%, and drug contents (98.97-101.21\%) were within the specified limits.

Surface $\mathrm{pH}$ of all the formulations was found to be between 5.5 and 7.5 (Figure 2), which seemed within the acceptable salivary $\mathrm{pH}$ range (5.5-7.0). It was inferred that the tablets would not produce local irritation to the mucosal surface.

\section{Moisture absorption ratio}

The moisture absorption ratio was calculated to assess the relative moisture absorption potential of polymers as well as their strengths to maintain the integrity of the formulation after that absorption. The prepared tablets were subjected to such studies and the results are shown in Figure 3. Formulation F4

Table 5. Evaluation of preliminary batches for optimization of sustained release polymer

\begin{tabular}{llll}
\multirow{2}{*}{$\begin{array}{l}\text { Time } \\
\text { h) }\end{array}$} & \multicolumn{3}{l}{ Cumulative percentage drug release } \\
\cline { 2 - 4 } 0 & S1 & S2 & S3 \\
\hline 0 & 0 & 0 & 0 \\
\hline 1 & $18.23 \pm 0.56$ & $22.14 \pm 0.64$ & $30.23 \pm 0.54$ \\
\hline 2 & $26.60 \pm 0.64$ & $39.89 \pm 0.84$ & $36.02 \pm 0.64$ \\
\hline 3 & $35.11 \pm 0.68$ & $47.02 \pm 0.24$ & $41.05 \pm 0.66$ \\
\hline 4 & $46.12 \pm 0.67$ & $57.64 \pm 0.26$ & $56.31 \pm 0.52$ \\
\hline 5 & $57.46 \pm 0.62$ & $63.74 \pm 0.34$ & $71.26 \pm 0.34$ \\
\hline 6 & $64.34 \pm 0.54$ & $73.23 \pm 0.28$ & $83.27 \pm 0.25$ \\
\hline 7 & $73.23 \pm 0.45$ & $83.37 \pm 0.94$ & $98.63 \pm 0.47$ \\
\hline 8 & $79.26 \pm 1.20$ & $90.54 \pm 0.34$ & - \\
\hline 9 & $86.23 \pm 0.87$ & $91.23 \pm 0.67$ & - \\
\hline 10 & $90.14 \pm 0.67$ & $101.2 \pm 0.84$ & - \\
\hline 11 & $95.46 \pm 0.75$ & - & - \\
\hline 12 & $100.47 \pm 0.84$ & - & - \\
\hline
\end{tabular}

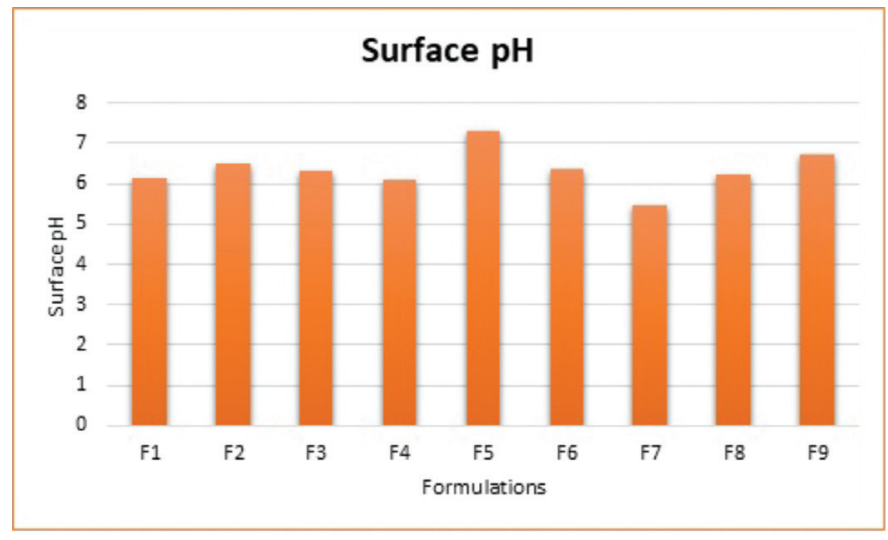

Figure 2. Surface $\mathrm{pH}$ of factorial batches 
was found to have the minimum value (28\%), whereas F8 had the maximum value (51\%), which may be attributed to the high concentration of hydrophilic neem gum.

\section{Ex vivo mucoadhesive strengths and time}

The ex vivo mucoadhesive strengths and time of the tablets were determined for all formulations using goat buccal mucosa. The mucoadhesive strengths and time were found to be increased with increased concentrations of polymers. The best bioadhesive strength was found for F9 (21.28 g) and the lowest for F1 $(17.25 \mathrm{~g})$. The mucoadhesion was attributed to the formation of a hydrogen bond between polymers due to swelling and mucin of the mucus membrane. F9 was prepared with higher concentrations of neem gum and HPMC, which might have resulted in high swelling and ultimately higher values of mucoadhesion. Figure 4 shows the results obtained from the test. This test indicated the mucoadhesive potential of polymers used in formulations.

\section{In vitro drug release studies}

The prepared factorial tablets were subjected to in vitro dissolution studies for $12 \mathrm{~h}$ to check the effect of the various concentrations of neem gum with HPMC K100M and the results are given in Figure 5. The dissolution pattern was found to be

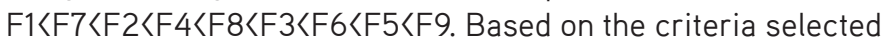
according to the theoretical drug release profile of nicorandil

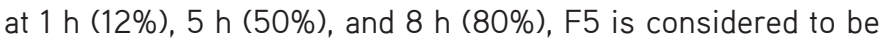

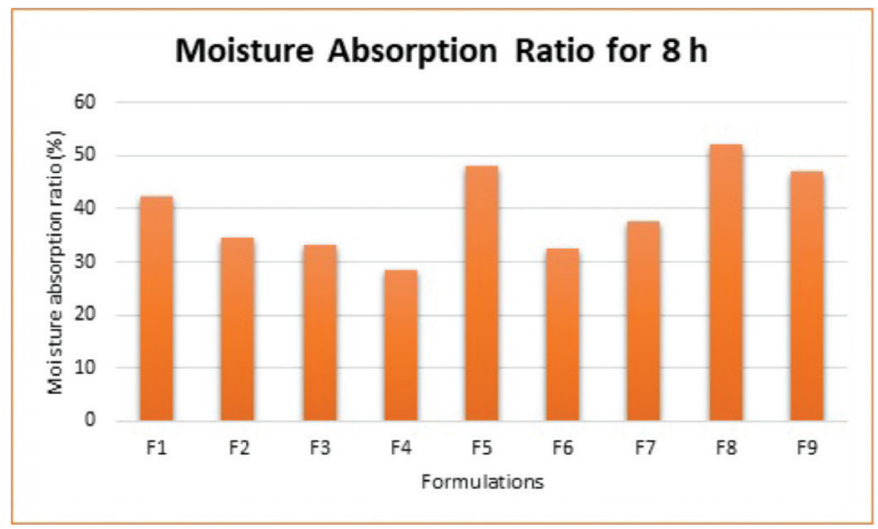

Figure 3. Moisture absorption ratio for $8 \mathrm{~h}$ of factorial batches

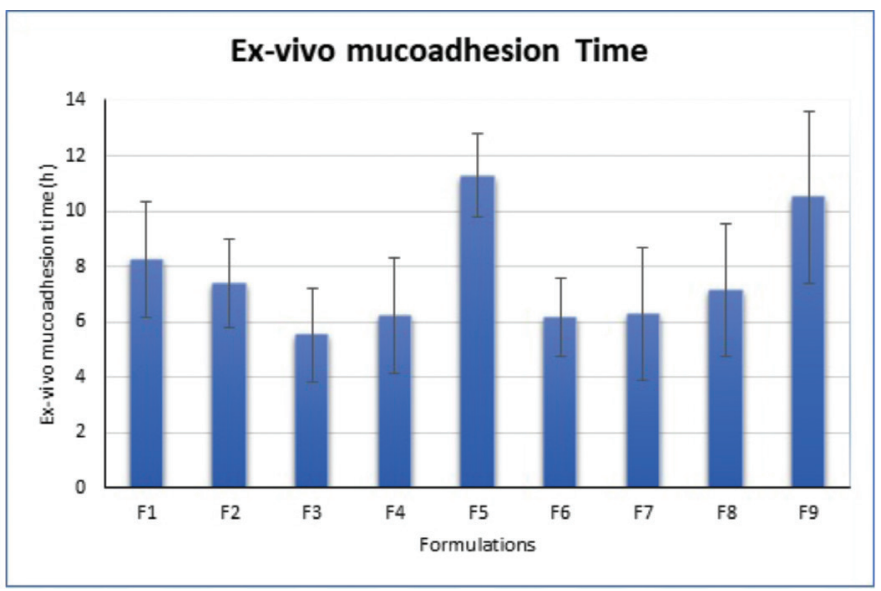

Figure 4. Ex vivo mucoadhesion time of factorial batches promising as it had drug release of $11.25 \%$ at $1 \mathrm{~h}, 51.81 \%$ at 5 $\mathrm{h}$, and $79.20 \%$ at $8 \mathrm{~h}$. Additionally, it sustained the drug release for $12 \mathrm{~h}$, which was attributed to the synergistic effect that occurred due to the presence of HPMC K100M as well as neem gum. To ensure the drug release kinetics from the optimized buccal tablet, the dissolution profile was fitted to different release kinetic models: zero-order, first-order, Hixson-Crowell, Higuchi, and Weibull's equations. The regression analysis was performed for batch $\mathrm{F} 5$ and residual values were used to analyze the best fit of the experimental data to the predicted models $\left(r^{2}>0.99\right.$ and minimum residual mean square and model parameters). The results are shown in Figure 6. As can be seen, the zero-order model was suited best to the dissolution data for F5, which suggested that the rate of drug release was perpetual over the course of time independent of the drug concentration.

\section{Ex vivo permeation studies}

Ex vivo permeation studies $(n=3)$ were performed for the optimized buccal tablet (F5). The slope, flux, and permeability coefficient for various formulations were $0.623,0.889 \pm 0.12$, and $0.241 \pm 0.07$, respectively. Cumulative percentage of drug permeated from the prepared formulation is shown in Figure 7. The results of the permeation study affirmed that the drug was liberated controllably from the tablet and impregnated steadily through the porcine buccal membrane and could possibly be infiltrated through the human buccal membrane as well.

\section{Statistical analysis}

\section{ANOVA studies}

A total of nine formulations were advised by the $3^{2}$ factorial design for two independent variables: the amount of neem gum $\left(X_{1}, \mathrm{mg}\right)$ and HPMC K100M ( $\left.X_{2}, \mathrm{mg}\right)$. The effect of these factors on $Y_{60}$ (release in $60 \mathrm{~min}$ ), $\mathrm{Y}_{240}$ (release in $240 \mathrm{~min}$ ), $\mathrm{T}_{50 \%}$ (time in min required for $50 \%$ release), and mucoadhesive strength in gram force (MS) was examined as response parameters in the study. Summaries of the variables and observed responses are given in Tables 6 and 7. The software Design Expert 7.0

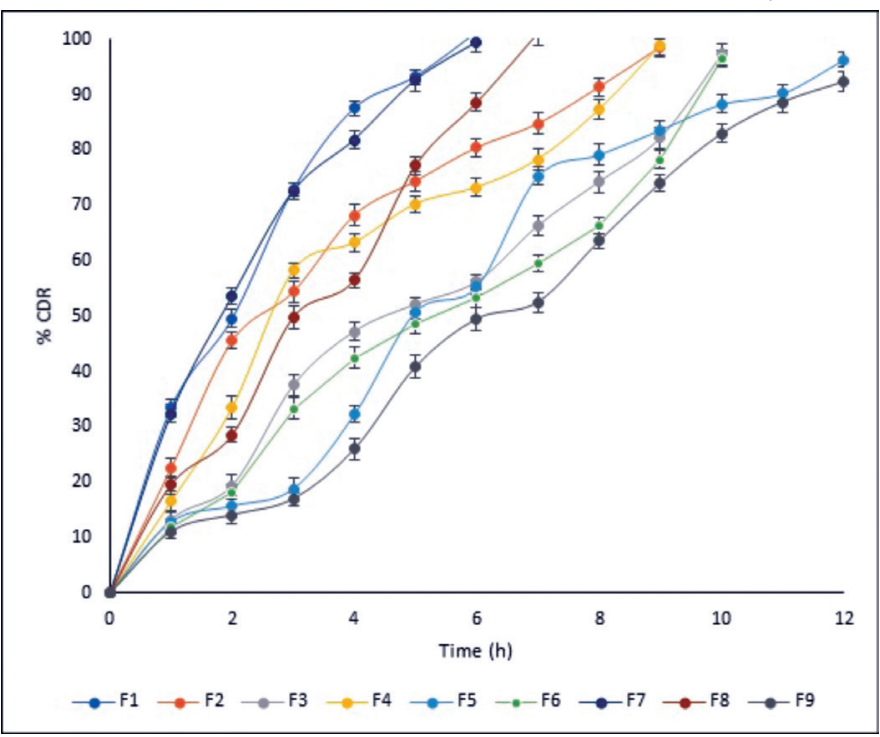

Figure 5. Cumulative percentage drug release profiles 


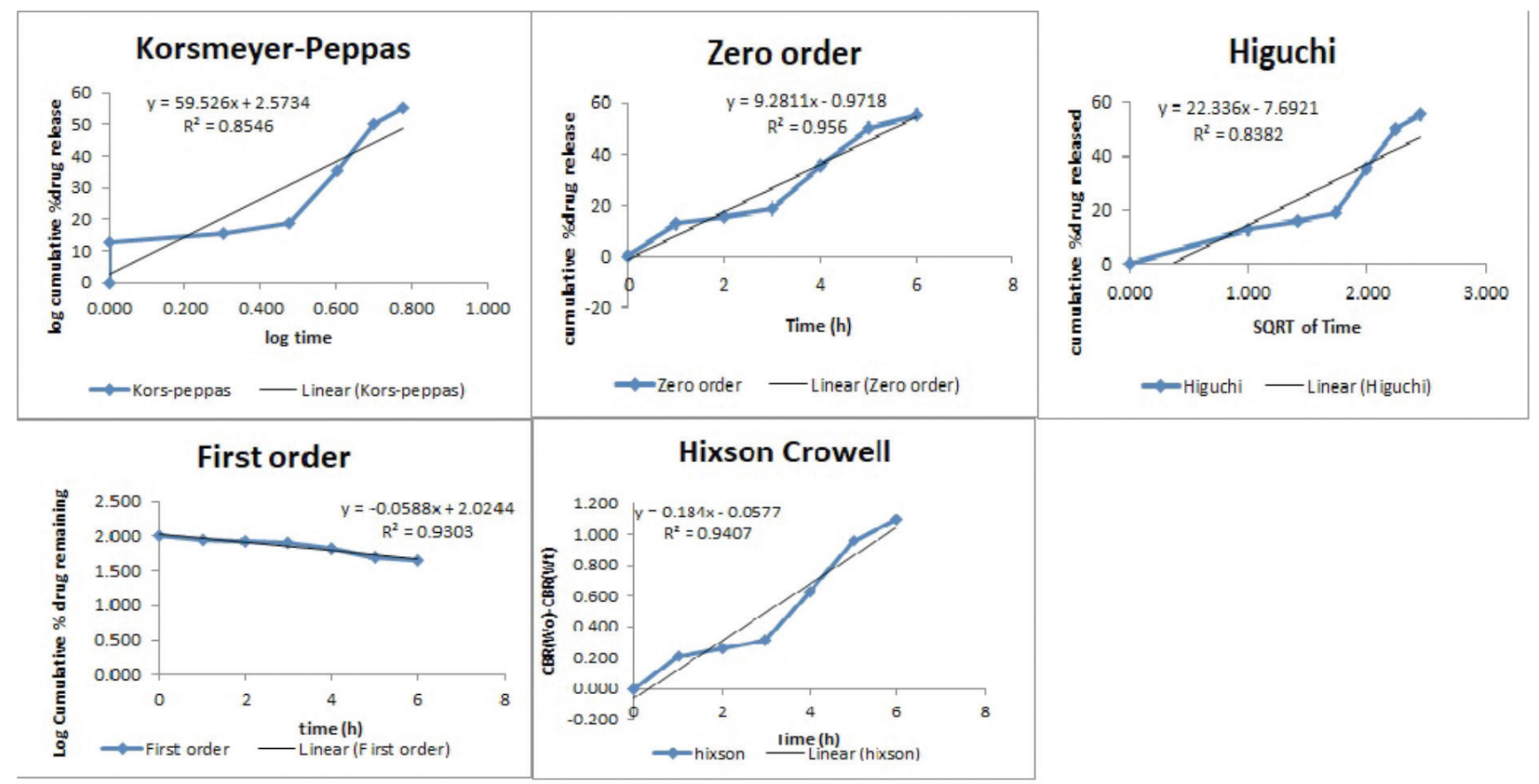

Figure 6. Release kinetics results of the optimized formulation (F5)

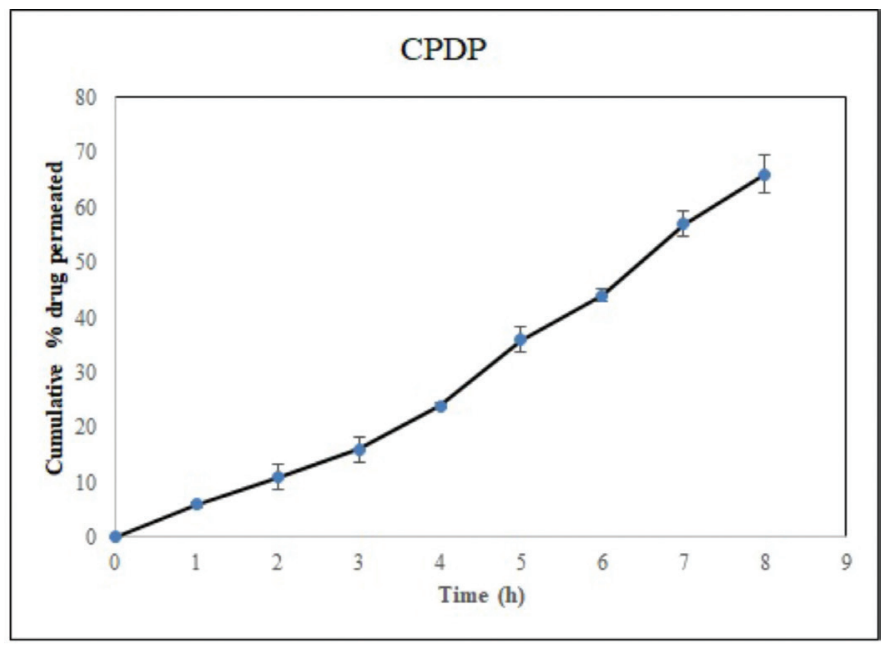

Figure 7. Cumulative percentage drug permeation of F5

calculated suitable model equations after fitting these data. According to the ANOVA results, all the models were significant ( $p<0.05)$. Model simplification was carried out by eliminating nonsignificant terms ( $p>0.05)$ in the equations, giving the model equation relating

$Y_{60}=20.60-8.95 X_{1}+0.6050 X_{2}$

Equation no (1)

$Y_{240}=56.61-18.74 X_{1}-5.88 X_{2}$

Equation no (2)

$\mathrm{T}_{50 \%}=221.22+88.67 \mathrm{X}_{1}+14.50 \mathrm{X}_{2}$

Equation no (3)

$M S=18.99+0.8183 X_{1}+1.07 X_{2}$

Equation no (4)

The data obviously demonstrated that the response values are strongly dependent on the independent variables chosen. From the equations (1-4), it was established that the independent
Table 6. Response values for buccal tablet formulations as per experimental design

\begin{tabular}{lllll} 
Batch code & $\begin{array}{l}\mathrm{Y}_{60} \\
(\%)\end{array}$ & $\begin{array}{l}\mathrm{Y}_{240} \\
(\%)\end{array}$ & $\begin{array}{l}\mathrm{T}_{50} \\
(\mathrm{~min})\end{array}$ & $\begin{array}{l}\text { Mucoadhesive strength } \\
\text { (gram force) }\end{array}$ \\
\hline F1 & 33.42 & 87.52 & 120 & 17.25 \\
\hline F2 & 22.56 & 68.24 & 145 & 18.12 \\
\hline F3 & 11.32 & 47.56 & 275 & 18.23 \\
\hline F4 & 22.31 & 63.26 & 162 & 18.49 \\
\hline F5 & 12.83 & 32.3 & 350 & 18.42 \\
\hline F6 & 12.01 & 42.56 & 312 & 20.36 \\
\hline F7 & 32.38 & 81.81 & 110 & 19.22 \\
\hline F8 & 27.45 & 56.24 & 180 & 19.52 \\
\hline F9 & 11.10 & 30.01 & 337 & 21.28 \\
\hline
\end{tabular}

variables $\left(X_{1}\right.$ and $\left.X_{2}\right)$ have significant effects on the chosen responses. The effects of factors $\left(X_{1}\right.$ and $\left.X_{2}\right)$ on responses were demonstrated by plotting 3D surface plots and contour plots as shown in Figure 8. It was found that responses may be changed by a convenient choice of the levels of $X_{1}$ and $X_{2}$. The results of dependent variables were selected to check the suitability of the prepared tablets as a mucoadhesive sustained-release formulation. Based on the theoretical requirement to prepare a sustained-release tablet formulation of nicorandil, $Y_{60}$ should be $11.25 \%, Y_{240}$ should be $35 \%$, and $T_{50 \%}$ should be $300 \mathrm{~min}$. F5 was found to have results similar to the theoretically calculated requirements. Hence, it is considered to be the optimized formulation and can be explored further in future research. 

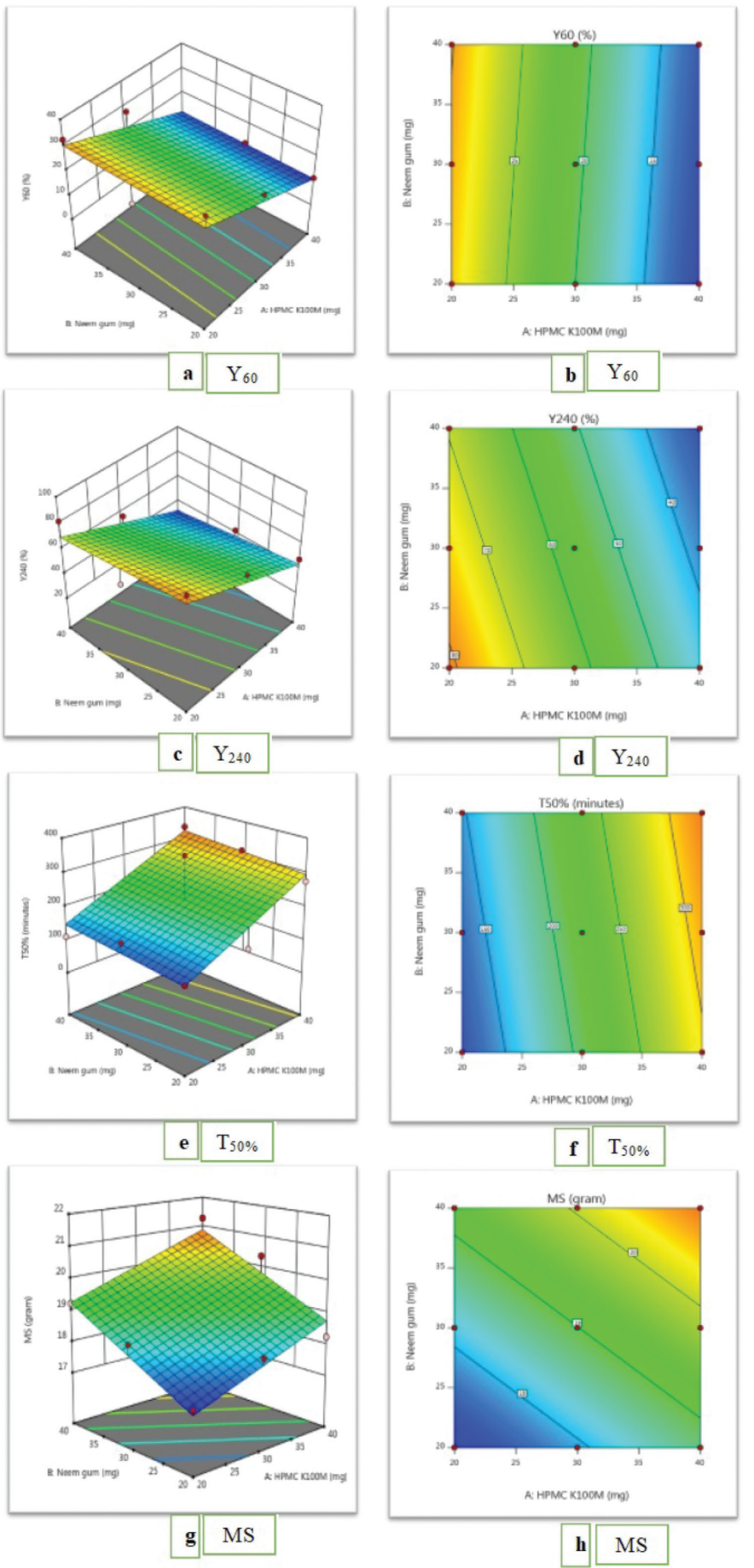

Figure 8. Surface plots (a, c, e, g) and contour plots (b, d, f, h) MS: Gram force

\section{Stability studies}

To assess the physicochemical nature of the optimized formulation (F5) with respect to dissolution characteristics and mucoadhesive strength, it was wrapped in aluminum foil and kept in the stability chamber with well-controlled conditions of temperature $\left(40 \pm 2^{\circ} \mathrm{C}\right)$ and humidity $(75 \pm 5 \% \mathrm{RH})$. After storage, dissolution parameters and mucoadhesive strength were determined and the results are depicted in Table 8. The precise way to find similarities between dissolution curves is to find
Table 7. ANOVA for linear model

$\mathrm{Y}_{60}$

\begin{tabular}{lccllll}
\hline Source & $\begin{array}{l}\text { Sum of } \\
\text { squares }\end{array}$ & df & $\begin{array}{l}\text { Mean } \\
\text { square }\end{array}$ & $F$ value & P value & \\
\hline Model & 482.45 & 2 & 241.23 & 7.83 & 0.0213 & Significant \\
\hline $\begin{array}{l}\text { A-HPMC } \\
\text { K10OM }\end{array}$ & 480.26 & 1 & 480.26 & 15.59 & 0.0076 & \\
\hline $\begin{array}{l}\text { B-neem } \\
\text { gum }\end{array}$ & 2.20 & 1 & 2.20 & 0.0713 & 0.7984 \\
\hline Residual & 184.89 & 6 & 30.81 & & \\
\hline Cor total & 667.34 & 8 & & & & \\
\hline
\end{tabular}

$\mathrm{Y}_{240}$

\begin{tabular}{|c|c|c|c|c|c|}
\hline Source & $\begin{array}{l}\text { Sum of } \\
\text { squares }\end{array}$ & $d f$ & $\begin{array}{l}\text { Mean } \\
\text { square }\end{array}$ & $F$ value & $p$ value \\
\hline Model & 2315.09 & 2 & 1157.54 & 6.72 & 0.0294 Significant \\
\hline $\begin{array}{l}\text { A-HPMC } \\
\text { K100M }\end{array}$ & 2107.88 & 1 & 2107.88 & 12.25 & 0.0128 \\
\hline $\begin{array}{l}\text { B-neem } \\
\text { gum }\end{array}$ & 207.21 & 1 & 207.21 & 1.20 & 0.3146 \\
\hline Residual & 1032.84 & 6 & 172.14 & & \\
\hline Cor total & 3347.93 & 8 & & & \\
\hline
\end{tabular}

$\mathrm{T}_{50 \%}$

\begin{tabular}{lllllll}
\hline Source & $\begin{array}{l}\text { Sum of } \\
\text { squares }\end{array}$ & df & $\begin{array}{l}\text { Mean } \\
\text { square }\end{array}$ & $F$ value & $p$ value & \\
\hline Model & 48432.17 & 2 & 24216.08 & 5.52 & 0.0437 & Significant \\
\hline $\begin{array}{l}\text { A-HPMC } \\
\text { K100M }\end{array}$ & 47170.67 & 1 & 47170.67 & 10.75 & 0.0168 & \\
\hline $\begin{array}{l}\text { B-neem } \\
\text { gum }\end{array}$ & 1261.50 & 1 & 1261.50 & 0.2876 & 0.6111 \\
\hline Residual & 26321.39 & 6 & 4386.90 & & \\
\hline Cor total & 74753.56 & 8 & & & \\
\hline
\end{tabular}

Mucoadhesive strength

\begin{tabular}{lllllll}
\hline Source & $\begin{array}{l}\text { Sum of } \\
\text { squares }\end{array}$ & df & $\begin{array}{l}\text { Mean } \\
\text { square }\end{array}$ & F value & p value \\
\hline Model & 10.89 & 2 & 5.44 & 21.71 & 0.0018 & Significant \\
\hline $\begin{array}{l}\text { A-HPMC } \\
\text { K100M }\end{array}$ & 4.02 & 1 & 4.02 & 16.03 & 0.0071 & \\
\hline $\begin{array}{l}\text { B-neem } \\
\text { gum }\end{array}$ & 6.87 & 1 & 6.87 & 27.40 & 0.0019 \\
\hline Residual & 1.50 & 6 & 0.2507 & & \\
\hline Cor total & 12.39 & 8 & & & \\
\hline
\end{tabular}

HPMC: Hydroxypropyl methylcellulose

out the similarity factor $f_{2}$ and the difference factor $f_{1}$. According to the food and drug administration, $f_{1}$ values less than 15 and $f_{2}$ values greater than 50 should establish an agreement between the dissolution curves, demonstrating an average disparity 
Table 8. Evaluation of stability studies of formulation (F5) for 3 months (mean $\pm S D, n=3$ )

\begin{tabular}{lll} 
Batch F5 & In vitro drug release at $12 \mathrm{~h}(\%)$ & Mucoadhesive strength (grams) \\
\hline Before storage & $96.35 \pm 1.54$ & $18.42 \pm 0.54$ \\
\hline After storage at $40 \pm 2^{\circ} \mathrm{C}$ and $75 \pm 5 \%$ relative humidity & $98.25 \pm 2.03$ & $20.56 \pm 1.20$ \\
\hline Similarity and dissimilarity $\left(f_{1} \& f_{2}\right)$ factor & $f_{1}=4$ & Not applicable \\
\hline
\end{tabular}

SD: Standard deviation

of no more than $10 \%$ at the sample time points. According to this guideline, the dissolution curves corresponding to F5 before storage were similar to those obtained with the same formulation after storage. No significant changes were found according to the results, which indicated that the prepared tablet formulation is stable.

\section{CONCLUSION}

To prevent the first-pass metabolism and provide sustained drug release, buccal drug delivery of nicorandil is considered to be one of the best surrogate routes of administration. Additionally, it will lead to patient compliance as well by reducing the frequency of administration. To attain this, a factorial approach was used with a combination of HPMC K100M and neem gum to prepare sustained-release buccal tablets of nicorandil that resulted in a sustained formulation, which can be used in a once a day tablet.

\section{ACKNOWLEDGMENTS}

The authors are thankful to Sun Pharma Laboratories Ltd., East Sikkim, for providing nicorandil as a gratis sample to carry out this research work.

Conflicts of interest: No conflict of interest was declared by the authors. The authors alone are responsible for the content and writing of this article.

\section{REFERENCES}

1. Ahmed AB, Nath LK. Design and development of controlled release floating matrix tablet of Nicorandil using hydrophilic cellulose and $\mathrm{pH}-$ independent acrylic polymer: in-vitro and in-vivo evaluations. Expert Opin Drug Deliv. 2016;13:315-324.

2. Falase B, Easaw J, Youhana A. The role of nicorandil in the treatment of myocardial ischaemia. Expert Opin Pharmacother. 2001;2:845-856.

3. Singh B, Garg T, Goyal AK, Rath G. Development, optimization, and characterization of polymeric electrospun nanofiber: a new attempt in sublingual delivery of nicorandil for the management of angina pectoris. Artif Cells Nanomed Biotechnol. 2016;44:1498-1507.

4. Krishnaiah YS, Al-Saidan SM, Chandrasekhar DV, Satyanarayana V. Controlled in vivo release of nicorandil from a carvone-based transdermal therapeutic system in human volunteers. Drug Deliv. 2006;13:69-77.

5. Prajapati G, Patel R. Design and in vitro evaluation of novel nicorandil sustained release matrix tablets based on combination of hydrophillic and hydrophobic matrix systems. International Journal of Pharmaceutical Sciences Review and Research. 2010;1:33-38.
6. Tamilvanan S, Babu VR, Nappinai A, Sivaramakrishnan G. In vitro and in vivo evaluation of hydrophilic and hydrophobic polymersbased nicorandil-loaded peroral tablet compared with its once-daily commercial sustained-release tablet. Drug Development and Industrial Pharmacy. 2011;37:436-445.

7. Boddupalli BM, Mohammed ZN, Nath RA, Banji D. Mucoadhesive drug delivery system: An overview. J Adv Pharm Technol Res. 2010;1:381387.

8. Chinna Reddy P, Chaitanya KS, Madhusudan Rao Y. A review on bioadhesive buccal drug delivery systems: current status of formulation and evaluation methods. Daru. 2011;19:385-403.

9. Hoogstraate JAJ, Wertz PW, Wertz PW. Drug delivery via the buccal mucosa. Pharmaceutical Science Technology Today. 1998;1:309-316.

10. Mohamed FAA, Roberts M, Seton L, Ford JL, Levina M, Rajabi-Siahboomi AR. Production of extended release mini-tablets using directly compressible grades of HPMC. Drug Dev Ind Pharm. 2013;39:1690-1697.

11. Nafee NA, Ismail FA, Boraie NA, Mortada LM. Mucoadhesive delivery systems. II. Formulation and in-vitro/in-vivo evaluation of buccal mucoadhesive tablets containing water-soluble drugs. Drug Dev Ind Pharm. 2004;30:995-1004.

12. Peh KK, Wong CF. Polymeric films as vehicle for buccal delivery: swelling, mechanical, and bioadhesive properties. J Pharm Pharm Sci. 1999;2:53-61.

13. Wong CF, Yuen KH, Peh KK. Formulation and evaluation of controlled release Eudragit buccal patches. Int J Pharm. 1999;178:11-22.

14. Yamsani VV, Gannu R, Kolli C, Rao ME, Yamsani MR. Development and in vitro evaluation of buccoadhesive carvedilol tablets. Acta Pharm. 2007;57:185-197.

15. Vueba ML, Batista de Carvalho LA, Veiga F, Sousa JJ, Pina ME. Influence of cellulose ether mixtures on ibuprofen release: MC25, HPC and HPMC K100M. Pharm Dev Technol. 2006;11:213-228.

16. Krishna LNV, Kulkarni PK, Dixit M, Lavanya D, Raavi PK. Brief introduction of natural gums, mucilages and their applications in novel drug delivery systems-a review. IJDFR. 2011;2:54-71.

17. Saha RN, Sajeev C, Sahoo J. A comparative study of controlled release matrix tablets of diclofenac sodium, ciprofloxacin hydrochloride, and theophylline. Drug Deliv. 2001;8:149-154.

18. Mohamad SA, Abdelkader H, Elrehany M, Mansour HF. Vitamin B12 buccoadhesive tablets: auspicious non-invasive substitute for intra muscular injection: formulation, in vitro and in vivo appraisal [published correction appears in Drug Dev Ind Pharm. 2019;45:x]. Drug Dev Ind Pharm. 2019;45:244-251.

19. Gupta A, Garg S, Khar RK. Measurement of bioadhesive strength of mucoadhesive buccal tablets: Design of an in-vitro assembly. Indian Drugs. 1993;30:152-155. 
20. Patel DM, Shah PM, Patel CN. Formulation and evaluation of bioadhesive buccal drug delivery of repaglinide tablets. Asian Journal of Pharmaceutics. 2014;6:171-179.

21. Daravath B, Swathi D, Rao BB. Formulation Development and Evaluation of Sustained Release Bioadhesive Bilayered Buccal Tablets of Furosemide. Analytical Chemistry Letters. 2017;7:215-277.

22. Biswal B, Karna N, Bhavsar B. Formulation and Evaluation of Repaglinide Buccal Tablet: Ex Vivo Bioadhesion Study and Ex Vivo Permeability Study. Journal of Applied Pharmaceutical Science. 2014;4:96-103.
23. Costa P, Sousa Lobo JM. Modeling and comparison of dissolution profiles. Eur J Pharm Sci. 2001;13:123-133.

24. Malaterre V, Ogorka J, Loggia N, Gurny R. Evaluation of the tablet core factors influencing the release kinetics and the loadability of push-pull osmotic systems. Drug Dev Ind Pharm. 2009;35:433-439.

25. Simionato LD, Petrone L, Baldut M, Bonafede SL, Segall Al. Comparison between the dissolution profiles of nine meloxicam tablet brands commercially available in Buenos Aires, Argentina. Saudi Pharm J. 2018;26:578-584. 